Int. J. Dev. Biol. 48: 1-7 (2004)

Original Article

\title{
The germ line and somatic stem cell gene Cniwi in the jellyfish Podocoryne carnea
}

\author{
KATJA SEIPEL*, NATHALIE YANZE and VOLKER SCHMID \\ Institute of Zoology, University of Basel, Pharmacenter, Basel, Switzerland
}

\begin{abstract}
In most animal phyla from insects to mammals, there is a clear division of somatic and germ line cells. This is however not the case in plants and some animal phyla including tunicates, flatworms and the basal phylum Cnidaria, where germ stem cells arise de novo from somatic cells. Piwi-like genes represent essential stem cell genes in diverse multicellular organisms. The cnidarian Piwi homolog Cniwi was cloned from Podocoryne carnea, a hydrozoan with a full life cycle. CniwiRNA is present in all developmental stages with highest levels in the egg and the medusa. In the adult medusa, Cniwi expression is prominent in the gonads where it likely functions as a germ stem cell gene. The gene is also expressed, albeit at low levels, in differentiated somatic cells like the striated muscle of the medusa. Isolated striated muscle cells can be induced to transdifferentiate into smooth muscle cells which proliferate and differentiate into nerve cells. Cniwi expression is upregulated transiently after induction of transdifferentiation and again when the emerging smooth muscle cells proliferate and differentiate. The continuous low-level expression of an inducible stem cell gene in differentiated somatic cells may underlie the ability to form medusa buds from polyp cells and explain the extraordinary transdifferentation and regeneration potential of Podocoryne carnea.
\end{abstract}

KEY WORDS: Cnidaria, evolution, germ line, Cniwi, Podocoryne carnea

\section{Introduction}

Separation of germ line and somatic cells occurs early in development of most animals including insects, roundworms and vertebrates. With the exception of the mammals, the determination of the primordial germ cells is brought about by the cytoplasmic localization of specific proteins and mRNAs in certain cells of the early embryo. In Drosophila, the germ cell lineage is defined by the localization of germ plasm determinants like Nanos RNA which then become localized by a protein scaffold (Ephrussi and Lehmann, 1992; Jongens et al., 1992; Nakamura et al., 1996). Later the primordial germ line cells migrate into the developing gonad primordia where they form the germ line stem cells (GSCs). Both the Nanos and Piwi genes are essential for GSC maintenance. Piwiis also needed for cell division of GSCs in both male and female flies (Lin and Spradling, 1997; Cox et al., 1998). Somatically, Piwi is needed to maintain stem cells. Loss of function in GSCs slows their division and disrupts germ cell development (Spradling et al., 2001). A second Piwigene, Aubergine, encodes a Drosophila polar granule component required for pole cell formation (Harris and McDonald, 2001) and for the RNAi-like silencing of the Stellate locus in testes (Schmidt et al., 1999). Mutations in
Aubergine also block RNAi activation during egg maturation and perturb translation control during oogenesis (Kennerdell et al., 2002). Piwi is expressed in both somatic niche cells and germ cells; i.e. in cells neighbouring the GSCs, in terminal filament and cap cells of the germarium as well as in the GSCs (Cox et al., 2000; Xie and Spradling, 2000). It encodes a highly basic nuclear protein well conserved in evolution. Piwi homologs have also been found in mouse (MiWi) and human (Hiwi), sea urchin (Seawi) and zebrafish (Ziwi) (Cox etal., 1998; Cikaluk et al., 1999; Qiao et al., 2002; Tan et al., 2002). The total number of Piwillike genes is four in human, five in flies and at least 24 members in C.elegans (Schwarz and Zamore, 2002). In mammals expression of Piwi homologous genes is restricted to the testis where they function in spermatogenesis and germ cell proliferation by regulating the stability of spermiogenic mRNAs (Deng and Lin, 2002).

In the entire plant kingdom and in several animal phyla including cnidarians, flatworms and tunicates, a clear division of somatic and germ line cells is not established. Plant germ stem cells do not differentiate from a pool of primordial germ cells, but rather arise de

Abbreviations used in this paper: GSC, germ stem cell; PAZ, Piwi, Argonaute and Zwille domain; PPD, PAZ and Piwi domain.

*Address correspondence to: Dr Katja Seipel. Institute of Zoology, Klingelbergstrasse 50, CH-4056 Basel. Switzerland. Fax: +41-61-267 1627.

e-mail: Katja.Seipel@unibas.ch 
novo from sub-epidermal somatic cells in the gonads. Moreover, most plant somatic cells can be isolated and give rise to a new individual organism. Arabidopsis has two Piwilike genes, Argonaut/Ago-1 and Zwille/Pinhead, known to be required for meristem cell maintenance (Bohmert et al., 1998; Moussian et al., 1998). Thus, Piwilike genes represent essential stem cell genes in diverse multicellular organisms (Benfey, 1999). The zooids of tunicates and the buds and polyps of many invertebrate phyla testify to the ability of somatic cells to give rise to new individuals (Liu and Berrill, 1948; Buss, 1987).

Genes for the germ plasm determinant Nanos are present in the hydrozoans Hydra magnipapillata and Podocoryne carnea, both representatives of the basal phylum Cnidaria (Mochizuki et al., 2000; Torras et al., in preparation). Here we analyzed the structure and expression of the cnidarian Piwi homologous gene, Cniwi, isolated from Podocoryne carnea, a hydrozoan with a full life cycle. In the adult medusa Cniwiis expressed not only in germ stem cells located in the male and female gonads but also in somatic cells with transdifferentiation and regeneration potential. This may be the genetic basis for the superb regeneration capacities of many cnidarian species and for the transdifferentiation potential of the Podocoryne carneastriated muscle that is peerless in the animal kingdom.

\section{Results}

\section{Identification of a highly conserved cnidarian Piwi ho- molog}

Both the Argonaute and Piwi protein subfamilies belong to the PAZ and Piwi domain (PPD) proteins sharing two conserved domains called PAZ (originally found in Piwi, Argonaute and Zwille proteins) and Piwi domain. The cnidarian Piwigene, Cniwi, was cloned from Podocoryne carnea larvae. The cDNA is 2843 bp with a putative start codon at position 79 followed by an open reading frame ending at position 2682 . The gene product of 867 amino acid residues is a genuine Piwi homologous protein with highly conserved PAZ and Piwi domains (Fig. $1 \mathrm{~A})$. Cniwi is most closely related to the deuterostome Piwi proteins with an amino acid identity of $44-46 \%$ in the PAZ and $57-59 \%$ in the Piwi domain. The amino-terminal 14 residues include three basic tetrapeptide repeats (Fig. 1B). Most notably, this sequence is conserved in the vertebrate Piwi proteins, but not in the echinoderm and insect proteins. The same is true for the four C-terminal hydrophobic residues that are fully conserved to the mammalian proteins. The phylogenetic analysis of the PPD proteins confirms the placement of the Podocoryne Cniwi protein within the Piwi subfamily (Fig. 1C).

\section{Expression patterns in larval development}

Cniwi RNA is present in all stages of the life cycle of Podocoryne carnea(Fig. 2A), with highest levels in the egg and the medusa (Fig. 2B). The RNA is present in the oocyte as maternal message. Cniwi-specific staining is randomly scattered in the egg cytoplasm (Fig. 3A) and evenly distributed into the blastomeres (Fig. $3 \mathrm{~B}, \mathrm{C}$ ). During the cleavage stages the staining intensity is much reduced possibly due to degradation of the maternal RNA after fertilization. After gastrulation but before an ECM separates the ectoderm from the endoderm Cniwi-specific staining is found in clusters of cells all over the embryo (Fig. 3D). After formation of the ECM when the larval cell types differentiate Cniwi-specific staining localizes to the endoderm of the planula larva (Fig. $3 \mathrm{E}-\mathrm{G}$ ). In the absence of appropriate markers the cell type(s) expressing Cniwi in the embryo and larva are not clearly identifiable. Expression levels are very low in the late larva (Fig. 2B). At this stage of development cell proliferation and the formation of new cell types is strongly reduced. The larva attaches to a suitable substratum and transforms into the primary polyp, the founder of the polyp colony (Fig. 2A). The biggest difference in Cniwi transcript levels exists between the barely expressing gastrozoid (feeding) polyp and the strongly expressing gonozoid (budding) polyp (Fig. 2B).

\section{Expression patterns in the developing and adult medusa}

Medusae are formed through budding from gonozoid polyps. The budding process starts with dedifferentiated and highly

A

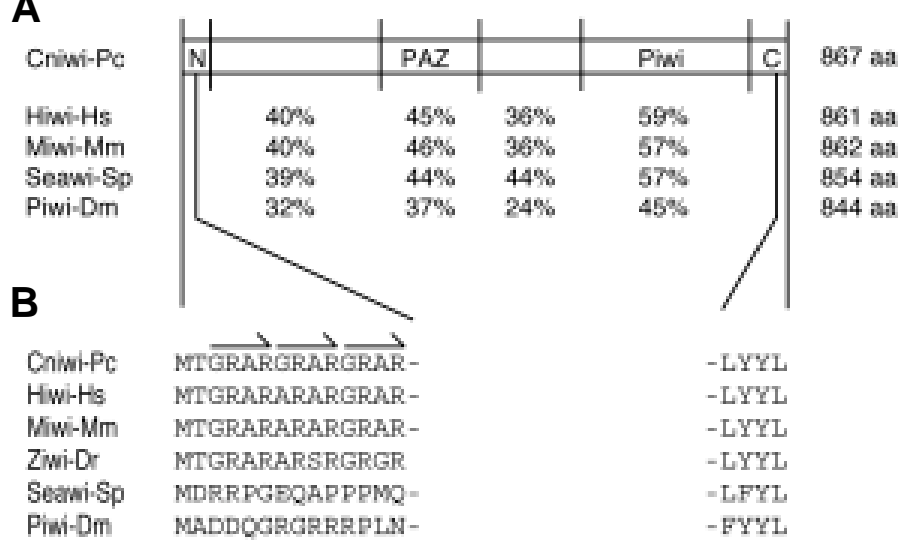

C

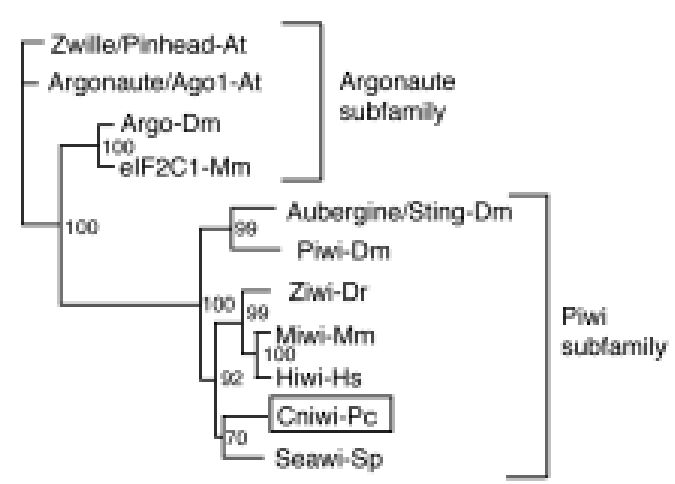

Fig. 1. Domain structure and sequence conservation in the Cniwi protein. (A) Domain structure and length of the Cniwi gene product and related sequences. Sequence conservation is indicated as percent identi$\mathrm{cal}$ amino acid residues within the domains and interdomains. Aminoterminal end (N), Piwi-argonaute-zwille domain (PAZ), Piwi domain and carboxy-terminal end (C). (B) Sequence conservation at the amino- and carboxy-terminal ends of the Cniwi protein. (C) Phylogenetic analysis of eumetazoan PPD proteins. The Cniwi protein belongs to the Piwi subfamily. At, Arabidopsis thaliana; Dm, Drosophila melanogaster; Dr, Danio rerio; Hs, Homo sapiens; Mm, Mus musculus; Pc, Podocoryne carnea; Sp, Strongylocentrotus purpuratus. All nodes with bootstrap values supported by less than $50 \%$ of replicates were collapsed. 
A

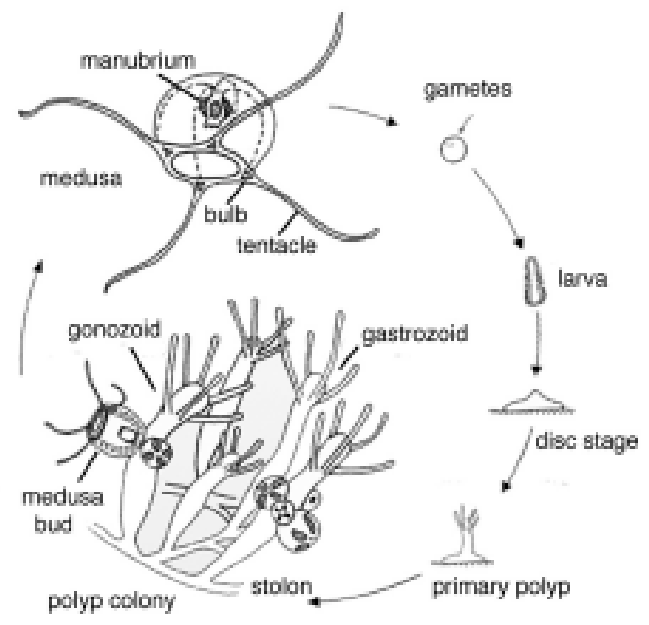

B

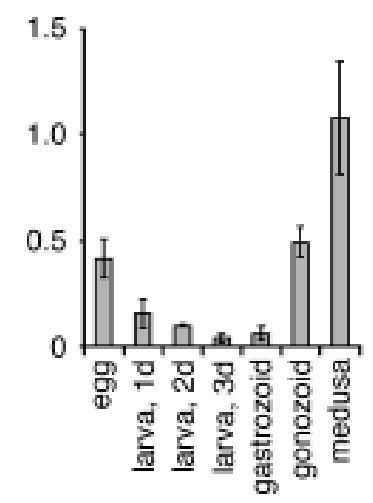

C

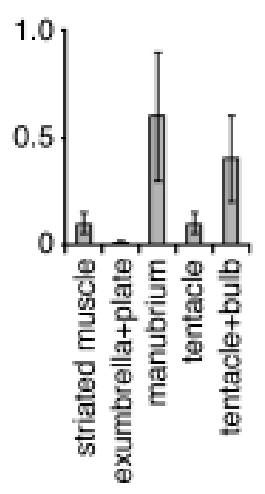

proliferative cells from both polyp ectoderm and endoderm (Fig. 4A). The medusa develops within one week and detaches from the polyp with vigorous muscle contractions. The histology of the budding process has been described and medusa buds were classified in 10 different stages (Frey, 1968). Cniwiexpression in the medusa bud primordia is weak (Fig. 4A). In early bud stages and during formation of the entocodon, entocodon cavity and manubrium anlage Cniwi expression is localized mostly to the endoderm (Fig. 4 B-D). With formation of the manubrium and muscle tissues at stage 5 Cniwispecific staining becomes restricted to the entocodon derived striated muscle and manubrial smooth muscle and the plate cells that derive from the radial canal endoderm (Fig. 4E). With formation of the gonads at stage 6 to 7 Cniwiis also expressed in the developing gonads and the underlying manubrial endoderm (Fig. 4 F,G). In later stages Cniwi specific staining is found predominantly in the gonads with some weak staining in the tentacle bulbs and the striated muscle (Fig. $4 \mathrm{H}-\mathrm{J}$ ). From stage 9 on and in the adult medusa cell proliferation occurs in the manubrium and the tentacle bulbs while it is absent from the tissues forming the bell (Spring et al., 2000).

In the adult medusa Cniwiis expressed in the manubrium and tentacle bulbs with low levels in the striated muscle and tentacles

Fig. 2. Cniwi expression in the life cycle of Podocoryne carnea. (A) Life cycle of the hydrozoan Podocoryne carnea. The fertilized egg of Podocoryne carnea develops into a ciliated planula larva. At the age of 30 to 35 hours, the larva is ready to attach to the substrate at its anterior pole and to transform into the primary polyp. After stolon outgrowth at the base of the primary polyp, a colony of feeding polyps (gastrozoids) and medusa budding polyps (gonozoids) develop asexually. In the mid-body region of the gonozoid, medusa buds of different developmental stages form a whorl. The medusa buds develop into medusae in 7 to 8 days and are classified according to their stage of differentiation from 1 to 10 (Frey, 1968). Quantitative RT-PCR expression analysis of (B) the life cycle stages and (C) different excised medusa parts. The ordinate values are relative expression levels normalized to the expression level of $\mathrm{EF} 1 \alpha$ and displayed in arbitrary units.

(Fig. 2C). By in situ hybridization Cniwi is expressed predominantly in the gonads, both in the spermatogonia (Fig. 5 A-D) and oogonia (Fig. $5 \mathrm{~F}, \mathrm{G}$ ) and at low levels in the tentacle bulbs (Fig. $5 \mathrm{~A}$ ) and tentacle endoderm (Fig. 5E).

\section{Expression during in vitro transdifferentiation}

There appears to be a positive correlation of Cniwiexpression with cell proliferation in larval development and in the manubrium and tentacle bulbs of the adult medusa. However, there is little or no Cniwispecific staining in highly proliferative tissues like the epidermal layer of the developing medusa at stages 3-6 (Fig. $4 \mathrm{D}$ G). Moreover, Cniwi is expressed, albeit at low levels, in nonproliferating differentiated cells like the striated muscle in the late
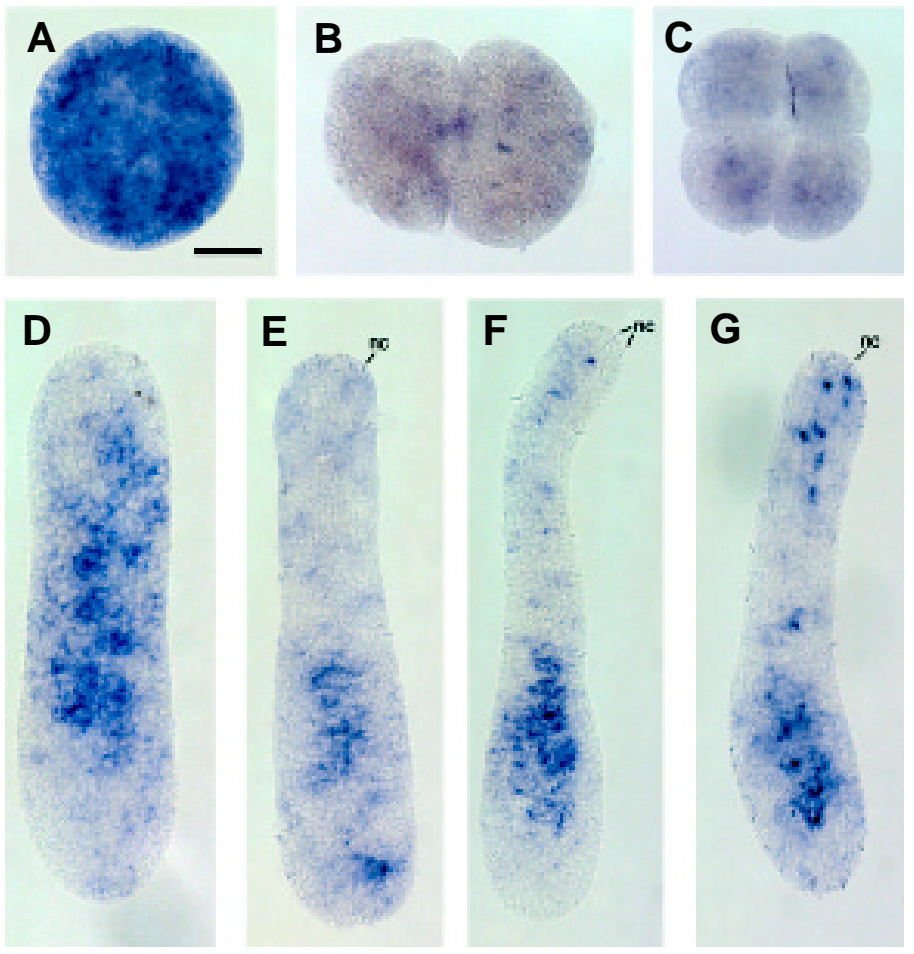

Fig. 3. Cniwi expression in embryogenesis and larval development. Whole mount in situ hybridization with Cniwi probe. (A) egg, (B) 2-cell stage, (C) 4-cell stage, (D) postgastrulation embryo, (E-G) larvae at 1-2 days of age. Bar, $50 \mu \mathrm{M}$. nc, nematocyte capsules. 

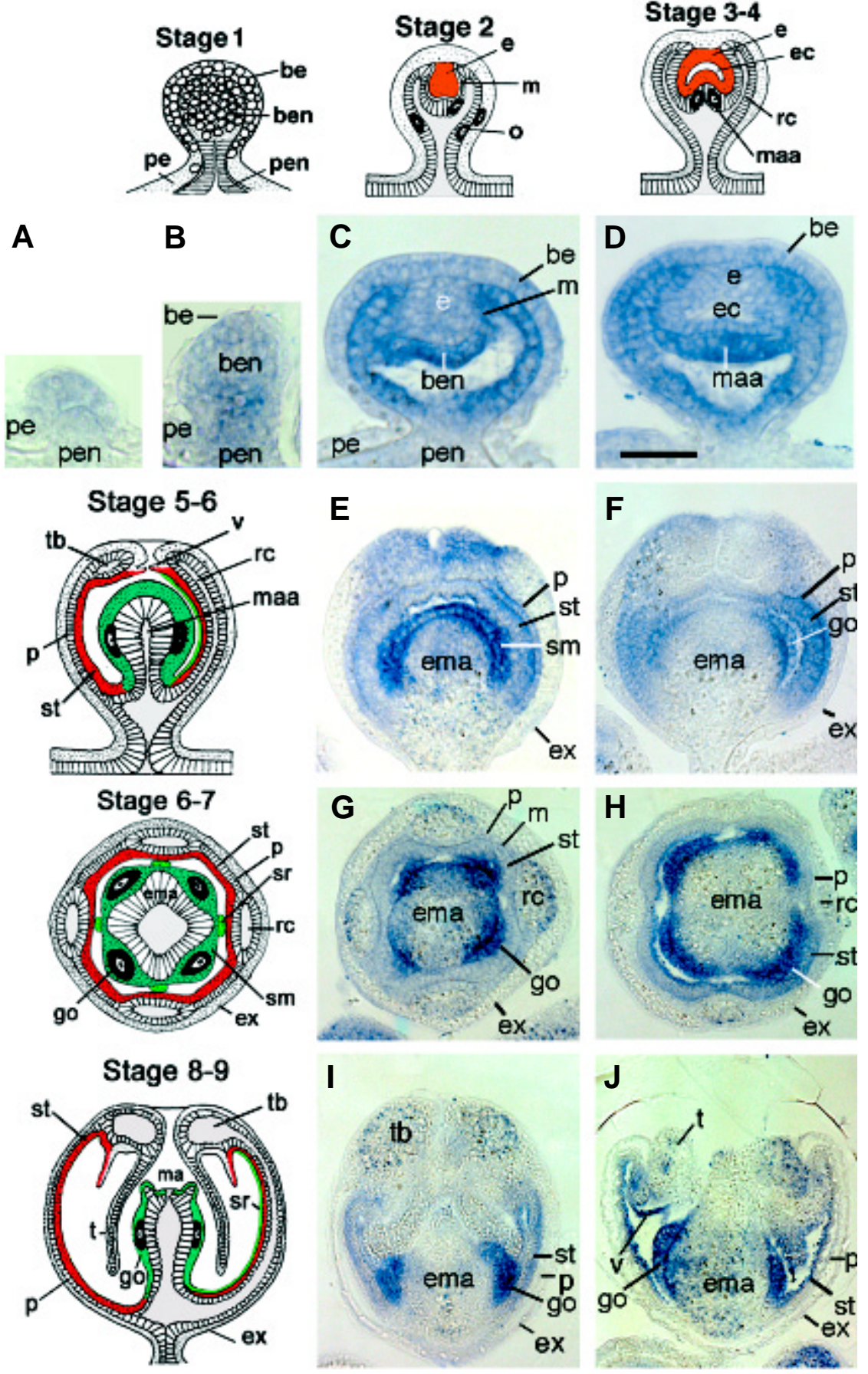

Fig. 4. Cniwiexpression during medusa development. Schematic drawings of Podocoryne medusa development and corresponding Cniwi expression patterns as revealed by in situ hybridization. (A- $F, I, J)$ sagittal sections. $(G, H)$ cross sections with bud stages: (A) 0 , (B) 1 , (C) 2, (D) 3/4, (E) 5, (F) 6, (G) 6/7, (H,I) 8/9 and (J) 10. Medusa buds were staged according to Frey (1968). Abbreviations: be, medusa bud ectoderm; ben, medusa bud endoderm; e, entocodon (brown), derived striated muscle (red), smooth muscle (green); ec, entocodon cavity; ema, endoderm of the manubrium; ex, exumbrella; go, gonads; $m$, mesoglea (ECM) separating entocodon from ectoderm and endoderm; ma, manubrium; maa, manubrium anlage; $p$, plate cells of the subumbrella; pe, polyp ectoderm; pen, polyp endoderm; rc, radial canal; sm, entocodon derived smooth muscle of the manubrium (dark green); sr, entocodon derived smooth muscle over the radial canal (light green); st, striated muscle (red); $t$, tentacle; tb, tentacle bulbs; $v$, developing velum. Bar, $100 \mu \mathrm{M}$ in (A-D); $150 \mu \mathrm{M}$ in (E); 200 $\mu M$ in $(F-H) ; 250 \mu M$ in $(I, J)$. bud stages (Fig. 4 I,J) and tentacle endoderm in the adult medusa (Fig. 5E). To investigate this correlation we used a well-defined in vitro transdifferentiation system (Schmid and Alder, 1984; Alder and Schmid, 1987). After isolation and enzymatic activation the striated muscle cells aggregate and transdifferentiate to smooth muscle cells that start to divide asymmetrically producing one proliferating smooth muscle cell and one non-proliferating differentiated RFamide positive nerve cell (Fig. 6A).

As expected from the RT-PCR analysis on excised striated muscle of the adult medusa (Fig. 2C) Cniwi is expressed at low levels in the mechanically isolated striated muscle (Fig. 6B). After enzymatic activation Cniwi expression is transiently upregulated probably as a direct response to the changed cell-matrix interactions instrumental in the activation process (Schmid and Reber-Müller, 1995). During transdifferentiation to smooth muscle cells Cniwiexpression increases continuously to reach maximal levels at day 3 when most cells undergo cell division.

\section{Discussion}

In most animals germ line cells are set apart from somatic development in the early embryo. In Cnidaria, however, a clear division of somatic and germ line cells is not established and germ stem cells arise de novo from somatic cells either at the budding site of the gonozoid polyp or in the manubrial endoderm underlying the gonads. The germ line cells may arise from somatic cells by mechanisms related to transdifferentiation, similar to the formation of proliferating smooth muscle cells from non-proliferating striated muscle cells (Schmid and Alder, 1984). In Podocoryne carnea the female germ line cells appear to arise from somatic cells in the budding area of the female gonozoid polyp and migrate to the manubrium anlage in the early medusa bud (Frey, 1968; Brändle, 1971; Boelsterli, 1977) as shown schematically in Fig. 4. The oocyte precursor cells then migrate from the manubrial endoderm to the gonads located in the manubrial epidermis where they mature. The somatic cell types that function as GSCs in Podocoryne carnea have not been identified. However, it has been shown that germ cells can arise in vitro from differentiated striated muscle cells (Schmid, 1982), a cell type that is not present in the budding area of the gonozoid polyp. Thus various types of somatic cells may be able to function as GSCs in vivo. Not much is known about the formation of the male germ line cells in Podocoryne carnea. The spermatogenic precursor cells may be formed at the budding site of the male gonozoid polyp and migrate to the developing gonads. Alternatively, 
Fig. 5. Cniwi expression in the adult medusa. Whole mount in situ hybridization with Cniwi probe. (A) Lateral view of adult male medusa. (B) The four male gonads magnified from (A). (C) Bottom view of male manubrium with four gonads. (D) Lateral view of the excised male manubrium with gonads. (E) Tentacle. (F) Lateral view of excised female manubrium with four gonads. (G) Female gonad. Abbreviations: ma, manubrium; $\mathrm{ml}$, manubrial lip; nc, nematocyte capsules; oc, oocyte; og, oogonia; spg, spermatogonia; $t$, tentacle; tb, tentacle bulb. Bar, $300 \mu \mathrm{M}$ in (A); $100 \mu \mathrm{M}$ in $(B, D) ; 150 \mu M$ in $(C, F) ; 75 \mu M$ in $(E, G)$.
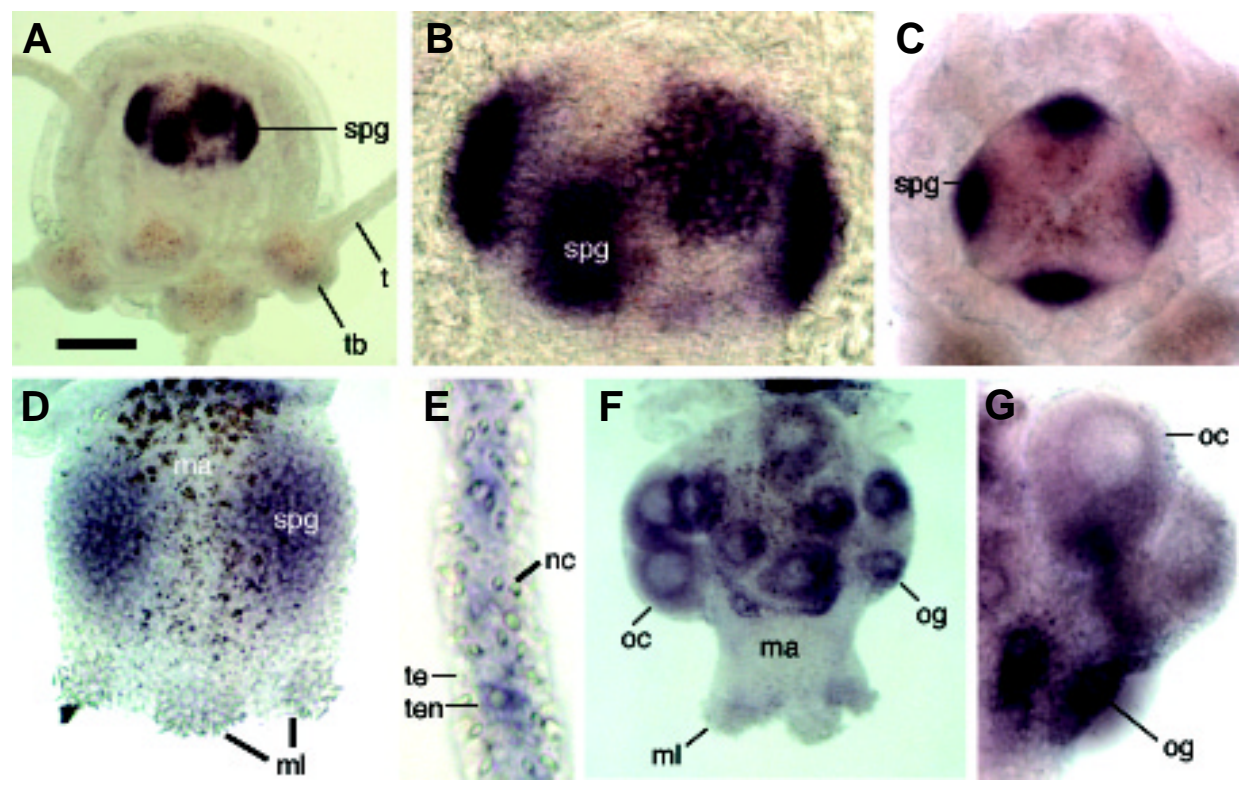

they may be formed in the manubrial endoderm underlying the gonads. In the developing male medusa the cnidarian Piwi homolog Cniwi is expressed predominantly in the gonads, and also in the manubrial endoderm underlying the gonads (Fig. 4 $F, G)$. One interpretation of the data is that male germ line cells arise from somatic cells in the manubrial endoderm. Another possibility is that Cniwi is expressed in both somatic niche cells and germ cells like in Drosophila (Cox et al., 2000; Xie and Spradling, 2000). In evolutionary terms both the conserved Nanos (Mochizuki et al., 2000; Torras et al., in preparation) and Piwilike genes are part of the molecular mechanisms of gametogenesis established early in evolution in the hypothetical common ancestor of Cnidaria and Bilateria.

A

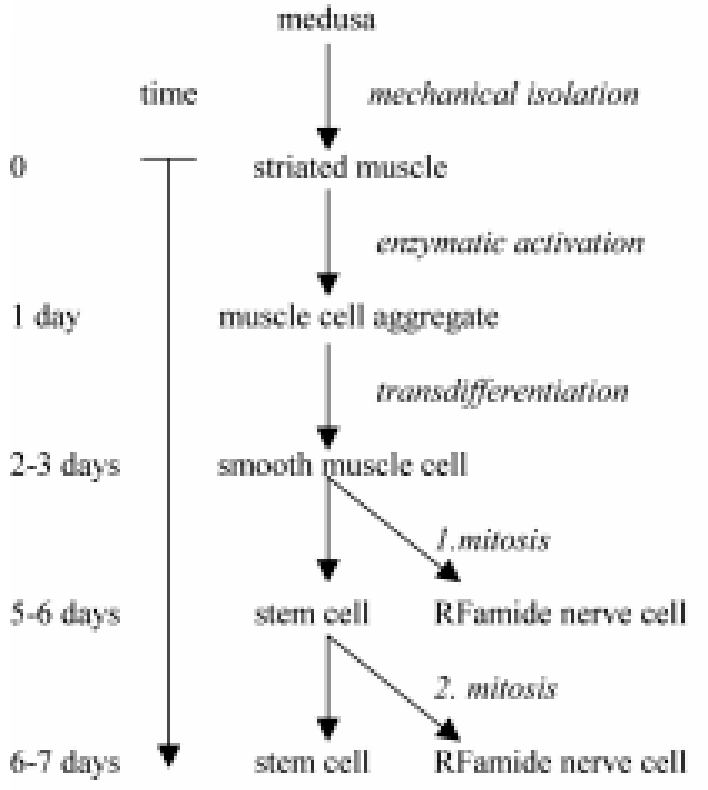

While most plant somatic cells can regenerate an entire new organism, regenerative abilities in bilaterian animals vary from very poor in mammals to excellent in flatworms where embryonic stem cells, called neoblasts, form all new cell types of the organism (Ladurner et al., 2000). Many cnidarian species have superb regeneration capacities (Galliot and Schmid, 2002; Holstein etal., 2003). The transdifferentiation potential of the isolated striated muscle of Podocoryne carnea (Hydrozoa, Cnidaria) is peerless in the animal kingdom (Schmid, 1992). This may be due to the ability to express and to fully reactivate the stem cell gene Cniwi in differentiated somatic cells (Fig. 6). In summary, Cniwi appears to be a general stem cell gene involved in germ and somatic stem cell maintenance, in transdifferentiation of somatic
B

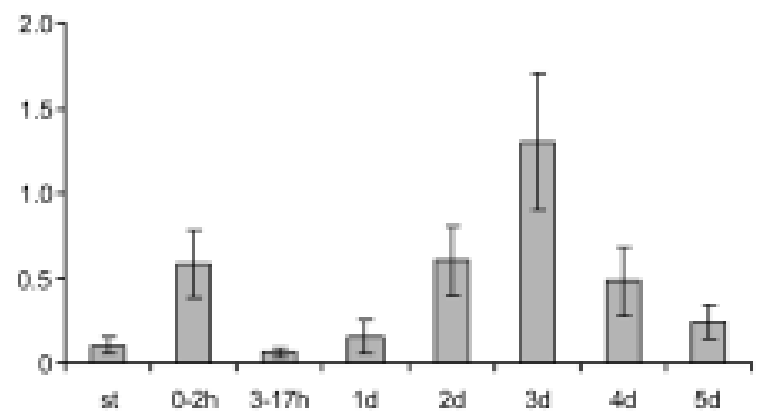

Fig. 6. Cniwi expression during in vitro transdifferentiation. (A) Flow chart and time course of transdifferentiation experiment. Isolated striated muscle of Podocoryne carnea can be activated by enzyme treatment to undergo transdifferentiation. The straited muscle cells transdifferentiate to proliferating smooth muscle cells and terminally differentiated RFamide neuropeptide positive nerve cells. (B) Quantitative RT-PCR expression analysis in isolated striated muscle (st), during activation (0-2 hours), in trans-differentiation (3 hours - 3 days) and during differentiation of nerve cells ( $4-5$ days). The ordinate values are relative expression levels normalized to the expression level of EF1 $\alpha$ and displayed in arbitrary units. 
cells and possibly in generation of germ stem cells from somatic cells.

\section{Materials and Methods}

\section{Animals}

Podocoryne carnea M. Sars (Cnidaria, Hydrozoa, Anthomedusae) colonies are reared in the laboratory in aerated artificial seawater at $16^{\circ} \mathrm{C}$. Animals were cultured on glass jars and fed every second day with two days old artemia. Medusa buds were staged according to Frey (1968). Eggs and larval stages were obtained as described (Aerne et al., 1995).

\section{Isolation of striated muscle tissue and initiation of transdifferentiation}

Striated muscle tissue was isolated and selected against contaminating cell types (Schmid and Alder, 1984) and transdifferentiation was initiated as described (Schmid and Reber-Müller, 1995).

\section{Molecular cloning and sequence comparison}

Molecular biology procedures were performed according to standard protocols (Sambrook and Russell, 2001). The 2843 bp full length Cniwi cDNA was obtained by extending the original 1124 bp clone by RACE. 5'RACE was done on larva SMART CDNA with nested SMART primers NUP1 (5'- AAG CAG TGG TAA CAA CGC AGA G - 3') and NUP2 (5'- TAA CAA CGC AGA GTA CGC GGG - 3') together with the gene-specific primers Piwi-R2 (5'- CTG GAT GTC TGG ATC GAA GCT AAC - 3') and Piwi-R3 (5'GAT GGA GAC CAG TAA AAT TTG GAA G - 3'). 3'- RACE was done on larval first strand CDNA synthesized with the modified oligo(dT) primer XT20V (5'- GGC AGG TCC TCG TTG ACT CGA GAC GT(20)A GC - 3') by AMV reverse transcriptase (Roche). For 3' RACE we used the nested XT20V-specific primers X1 (5'- GGC AGG TCC TCG TTG ACT CG - 3') and X2 (5'- GCA GGT CCT CGT TGA CTC GAG ACG - 3') together with the gene-specific primers Piwi-F2 (5'- GAA AAT GTC TGG CCG TAG TCT TCC - 3') and Piwi-F3 (5'- CTT CCA GCA GAA GAT ATG TTC CAG -3'). The Cniwicoding sequence has been submitted to the DNA databases with accession number AY493987. Nucleotide and deduced amino acid sequences were analyzed using the GCG software package. BLAST searches (Altschul et al., 1997) were performed using the BLAST network service at the NCBI (http://www.ncbi.nlm.nih.gov). Multiple sequence alignments and phylogenetic trees based on the neighbor-joining method were generated with Clustal X (Jeanmougin etal., 1998) and TREEPUZZLE (Schmidt et al., 2002). Accession numbers for published protein sequences used in Fig. 2 are as follows: Ago1-At, NP_849784; Argo-Dm, NP_523734; Aubergine-Dm, CAA64320; elF2C1-Mm, NP_700452; Hiwi-Hs, AAC97371; Miwi-Mm, NP_067286; Piwi-Dm, AAF53043; Seawi-Sp, AAG42533; ZiwiDr, NP_899181; Zwille-At, T52134.

\section{RT-PCR analysis}

mRNA from eggs, larvae, polyps, medusae and excised medusa parts was extracted using the Dynabeads mRNA Direct Kit (Dynal) as recommended by the manufacturer. 1st strand cDNA synthesis and real time PCR were carried out as described (Spring et al., 2000). The ubiquitously expressed elongation factor 1 alpha $(E F 1 \alpha)$ was included in each set of experiments as a reference to compensate for variations in the quantity and quality of preparations. PCR analysis was done in duplicates and in independent experiments. Cniwi expression was evaluated using the primers Piwi-F5 (5'- CGT TGC CTG ATC GAA TTA TTG TTT ACA -3') and Piwi-R4 (5' - CTC TGT TTT ACA AGT AAT ACA ATC GGT - 3'). Primers for EF/ $\alpha$ have been described (Yanze et al., 1999).

\section{In situ hybridization}

Parts of the CniwicDNA were amplified with specific primers Piwi-F1 (5'- CTT CCA AAT TTT ACT GGT CTC CAT - 3') and Piwi-R1 (5'- CTG GAA CAT ATC TTC TGC TGG AAG - 3') and cloned into the plasmid
pCRII-TOPO (TOPO TA cloning, Invitrogen). Templates for the antisense probes were prepared by amplification using the $\mathrm{M} 13$ reverse primer and the Piwi-F1 primer. DIG-labelled RNA probes were prepared from the templates with Sp6 RNA polymerase according to the manufacturer (Roche). In situhybridization with DIG-labelled probes was performed as described previously (Müller et al., 2003). Detection was performed by immunostaining with anti-DIG-Fab-AP (Roche) using NBT/BCIP as a substrate. Specimens were fixed for 2 hours at room temperature with $4 \%$ paraformaldehyde or with freshly prepared Lavdowsky solution. Stained specimens were postfixed for 2 hours at room temperature in $4 \%$ paraformaldehyde, dehydrated in ethanol, embedded in Paraplast (Sigma) and sectioned to $10 \mu \mathrm{m}$.

\section{Acknowledgements}

We are grateful to Ruth Streitwolf-Engel and Brigitte Winninger for technical support. This work was supported by the Swiss National Science Foundation.

\section{References}

AERNE, B.L., BAADER, C.D., and SCHMID, V. (1995). Life stage and tissuespecific expression of the homeobox gene cnox1-Pcof the hydrozoan Podocoryne carnea. Dev. Biol. 169: 547-556.

ALDER, H. and SCHMID, V. (1987). Cell cycles and in vitrotransdifferentiation and regeneration of isolated, striated muscle of jellyfish. Dev. Biol. 124: 358-69.

ALTSCHUL, S.F., MADDEN, T.L., SCHAFFER, A.A., ZHANG, J., ZHANG, Z., MILLER, W., LIPMAN, D.J. (1997). Gapped BLAST and PSI-BLAST: A new generation of protein database search programs. Nucleic Acids Res. 25: 3389-3402.

BENFEY, P.N. (1999). Stem cells: A tale of two kingdoms. Curr. Biol. 9: R171-172.

BOESTERLI, U. (1977). An electron microscopic study of early developmental stages, myogenesis, oogenesis and cnidogenesis in the anthomedusa Podocoryne carnea M. Sars. J. Morphol. 154: 259-289.

BOHMERT, K., CAMUS, I., BELLINI, C., BOUCHEZ, D., CABOCHE, M. and BENNING, C. (1998). Ago1 defines a novel locus of Arabidopsiscontrolling leaf development. EMBO J. 17: 170-180.

BRAENDLE, E. (1971). Bedeutung der kolonialen Komponenten für die Bildung und Differenzierung der Medusen von Podocoryne carnea M Sars. Wilhelm Roux Arch. 166: 254-286.

BUSS, L.W. (1987). The evolution of Individuality. Princeton University Press, Princeton, $\mathrm{NJ}$.

CICALUK, D.E., TAHBAZ, N., HENDRICKS, L.C., DIMATTIA, G.E., HANSEN, D., PILGRIM, D. and HOBMAN, T.C. (1999). GERp95, a membrane-associated protein that belongs to a family of proteins involved in stem cell differentiation. Mol. Biol. Cell. 10: 3357-3372.

COX, D.N., CHAO, A., BAKER, J., CHANG, L. and LIN H. (1998). A novel class of evolutionary conserved genes defined by Piwiare essential for stem cell selfrenewal. Genes Dev. 12: 3715-3727.

COX, D.N., CHAO, A., and LIN H. (2000). Piwi encodes a nucleoplasmic factor whose activity modulates the number and division rate of germline stem cells. Development: 127: 503-514

DENG, W. and LIN, H. (2002). Miwi, a murine homolog of Piwi, encodes a cytoplasmic protein essential for spermatogenesis. Dev. Cell: 2: 819-830.

EPHRUSSI, A. and LEHMANN, R. (1992). Induction of germ cell formation by oskar. Nature 358: 387-392.

FREY, J. (1968) Die Entwicklungsleistungen der Medusenknospen und Medusen von Podocoryne carnea M.Sars nach Isolation und Dissoziation. Wilhelm Roux Arch. 160: 428-464.

GALLIOT, B. and SCHMID, V. (2002). Cnidarians as a model system for understanding evolution and regeneration. Int. J. Dev. Biol. 46: 39-48.

HARRIS, A.N. and MACDONALD, P.M. (2001). Aubergine encodes a Drosophila polar granule component required for pole cell formation and related to elF2C. Development 128: 2823-2832.

HOLSTEIN, T.W., HOBMAYER, E. and TEHNAU, U. (2003). Cnidarians: an evolutionarily conserved model system for regeneration? Dev Dyn. 226: 257-67. 
JEANMOUGIN, F., THOMPSON, J.D., GOUY, M., HIGGINS, D.G. and GIBSON, T.J. (1998). Multiple sequence alignment with Clustal X. Trends Biochem. Sci. 23: $403-405$.

JONGENS, T.A., HAY, B., JAN, L.Y. and JAN, Y.N. (1992). The germ-cell less gene product: A posteriorly localized component necessary for germ cell development in Drosophila. Cel/70: 569-584.

KENNERDELL, J.R., YAMAGUCHI, S. and CARTHEW, R.W. (2002). RNAi is activated during Drosophila oocyte maturation in a manner dependent on aubergine and spindle-E. Genes Dev. 16: 1884-1889.

LADURNEN, P., RIEGER, R., BAGUNA, J. (2000). Spatial distribution and differentiation potential of stem cells in hatchlings and adults in the marine platyhelminth Macrostomumsp.: a bromodeoxyuridine analysis. Dev Biol. 226, 231-41.

LIN, H. and SPRADLING, A.C. (1997). A novel group of pumilio mutations affects the asymmetric division of germline stem cells in the Drosophila ovary. Development 124: 2463-2476.

LIU, C. K. and BERRILL, N. J. (1948). Gonophore formation and germ cell origin in Tubularia. J. Morphol. 83: 39-60.

MOCHIZUKI. K., SANO, H., KOBAYASHI. S., NISHIMIYA-FUJISAWA. C. and FUJISAWA. T. (2000). Expression and evolutionary conservation of nanosrelated genes in Hydra. Dev Genes Evol. 210: 591-602.

MOUSSIAN, B., SCHOOF, H., HAECKER, A., JURGENS, G. and LAUX, T. (1998). Role of the $z$ willegene in the regulation of central shoot meristem cell fate during Arabidopsis embryo-genesis. EMBO J. 17: 1799-1809.

MUELLER, P., SEIPEL, K., YANZE, N., REBER-MUELLER, S., STREITWOLFENGEL, R., STIERWALD, S., SPRING, J. and SCHMID, V. (2003). Evolutionary aspects of developmentally regulated helix-loop-helix transcription factors in striated muscle of jellyfish. Dev. Biol. 255: 216-229.

NAKAMURA, A., AMIKURA, R., MUKAI, M., KOBAYASHI, S. and LASKO, P.F. (1996). Requirement for a non-coding RNA in Drosophila polar granules for germ cell establishment. Science 274: 2075-2079.

QIAO, D., ZEEMAN, A.M., DENG, W., LOOIJENGA, L.H.J. and LIN H. (2002). Molecular characterization of hiwi, a human member of the piwigene family whose expression is correlated to seminomas. Oncogene 21: 3988-3999.

SAMBROOK, J. and RUSSELL, D.W. (2001). Molecular Cloning: a Laboratory Manual, third ed. Cold Spring Harbor Laboratory Press, Cold Spring Harbor, NY.

SCHMID, V. (1982). Transdifferentiation and Regeneration in vitro. Dev. Biol. 92: 476-488.
SCHMID, V. (1992). Transdifferentiation in Medusae. Internat. Rev. Cyt. 142: 213-261.

SCHMID, V. and ALDER, H. (1984). Isolated, mononucleated, striated muscle can undergo pluripotent transdifferentiation and form a complex regenerate. Cel/38: 801-809.

SCHMID, V., and REBER-MUELLER, S. (1995). Transdifferentiation of isolated striated muscle of jellyfish in vitro. the initiation process. Semin. Cell Biol. 6: 109116.

SCHMIDT, A., PALUMBO, G., BOZZETTI, M.P., TRITTO, P., PIMPINELLI, S., and SCHAFER, U. (1999). Genetic and molecular characterization of sting, a gene involved in crystal formation and meiotic drive in the male germ line of Drosophila melanogaster. Genetics 151, 749-60.

SCHMIDT, H.A., STRIMMER, K., VINGRON, M., VON HAESELER, A. (2002). TREEPUZZLE: maximum likelihood phylogenetic analysis using quartets and parallel computing. Bioinformatics 18: 502-504.

SCHWARZ, D.S. and ZAMORE, P.D. (2002). Why do miRNAs live in the miRNP? Genes Dev. 16: 1025-1031.

SPRADLING, A.C., DRUMMOND-BARBOSA, D. and KAI T. (2001). Stem cells find their niche. Nature 414: 98-104.

SPRING, J., YANZE, N., MIDDEL, A., STIERWALD, M., GROEGER, H. and SCHMID, V. (2000). Ancestral role of the mesoderm specification factor Twistin the life cycle of jellyfish. Dev. Biol. 228: 363-375.

TAN, C.H., LEE, T.C., WEERARATNE, S.D., KORZH, V., LIM, T.M., GONG, Z (2002). Ziwi, the zebrafish homologue of the Drosophila piwi. co-localization with vasa at the embryonic genital ridge and gonad-specific expression in the adults. Gene Expr. Pat. 2: 257-60.

XIE, T. and SPRADLING, A.C. (2000). A niche maintaining germ line stem cells in the Drosophila ovary. Science 290: 328-330.

YANZE, N., GROEGER, H., MUELLER, P. and SCHMID, V. (1999). Reversible inactivation of cell-type-specific regulatory and structural genes in migrating isolated striated muscle cells of jellyfish. Dev. Biol. 213: 194-201.

Received: December 2003 Reviewed by Referees: January 2004 Modified by Authors and Accepted for Publication: January 2004 